doctoral graduates in clinical psychology from professional schools rose from $39 \%$ in 1987 to $59 \%$ in 1995 .

\section{References}

American Psychological Association. (1996). The Committee for the Advancement of Professional Practice (CAPP) practitioner survey. Washington, DC: Author.

American Psychological Association. (1997a). Directory of the American Psychological Association, 1997 edition. Washington, DC: Author.

American Psychological Association. (1997b). Graduate study in psychology, 1996 edition with 1997 addendum. Washington, DC: Author.

Belar, C. D. (1998). Graduate education in clinical psychology. American Psychologist, 53, 456-464.

Edwards, K. J. (1996, August). A comprehensive survey of National Council of Schools and Programs of Professional Psychology. Paper presented at the 104th Annual Convention of the American Psychological Association, Toronto, Ontario, Canada.

Eisman, E. J., Dies, R. R., Finn, S. E., Eyde, L. D., Kay, G. G., Kubiszyn, T. W., Meyer, G. J., \& Moreland, K. L. (1998, June). Problems and limitations in the use of psychological assessment in contemporary healthcare delivery: Report of the Roard of Professional Affairs $P_{s y-}$ chological Assessment Work Group, Part II. Washington, DC: American Psychological Association.

Eyde, L. D., Moreland, K. L., Robertson, G. J., Primoff, E. S., \& Most, R. B. (1988). Test user qualifications: A data-based approach to promoting good test use. Issues in scientific psychology. Washington, DC: American Psychological Association, Science Directorate.

Eyde, L. D., Robertson, G. I., Krug, S. E., Moreland, K. L., Robertson, A. G., Shewan, C. M., Harrison, P. L., Porch, B. E., Hammer, A. L., \&
Primoff, E. S. (1993). Responsible test use: Case studies for assessing human behavior. Washington, DC: American Psychological Association.

Garb, H. N. (1998). Studying the clinician: Judgment research and psychological assessment. Washington, DC: American Psychological Association.

Greenberg, S., Smith, I. L., \& Muenzen, P. M. (1995). Executive summary: Study of the practice of licensed psychologists in the United States and Canada. New York: Professional Examination Service.

Levant, R. F. (1998, August). We do live in "interesting times." In M. B. Kenkel (Chair), Training psychologists for the future: Perspectives of professional school executives. Symposium conducted at the 106th Annual Convention of the American Psychological Association, San Fran cisco, CA.

Meyer, G. J., Finn, S. E., Eyde, L. D., Kay, G. G., Kubiszyn, T. W., Moreland, K. L., Eisman, E. J., \& Dies, R. R. (1998, June). Benefits and costs of psychological assessment in healthcare delivery: Report of the Board of Professional Affairs Psychological Assessment Work Group. Part L. Washington, DC: American Psychological Association.

Moreland, K. L., Eyde, L. D., Robertson, G. J., Primoff, E. S., \& Most, R. B. (1995). Assessment of test user qualifications: A research-based measurement procedure. American Psychologist, 50, 14-23.

Norcross, J. C., Karg, R. S., \& Prochaska, J. O. (1997). Clinical psychologists in the 1990s: Part II. The Clinical Psychologist, 50, 4-11.

Sleek, S. (1998, March). Despite managed care, psychologists are committed to independent practice. APA Monitor, p. 23

Received April 6, 1999

Revision received November 8, 1999

Accepted December 2, 1999

\title{
Correction to "Acknowledgment of Ad Hoc Reviewers, 1999"
}

In "Acknowledgment of Ad Hoc Reviewers, 1999" (Professional Psychology: Research and Practice, Vol. 30, No. 6, p. 628), the following reviewer's name was inadvertently left out: Martha M. Woods. 